\title{
PODERES, DIREITO E DOMINAÇÃO: A TOMADA DE CONSCIÊNCIA E A INCLUSÃO DE OUTROS SUJEITOS A PARTIR DE QUESTÕES RACIAIS
}

\section{Paulo Fernando Soares Pereira}

Doutorando em Direito, Constituição e Democracia pela Universidade de Brasília - UnB. São Luís, MA, Brasil. paulofsp1983@gmail.com

\section{Ana Cláudia} Farranha

Doutora em Ciências

Sociais pela Universidade de Campinas. Professora da Universidade de BrasíliaUnB. Brasília, DF, Brasil. anclaud@uol.com.br

Recebido: junho 10, 2017

Aceito: outubro 8, 2017

\section{Powers, Law and Domination: The awareness and inclusion of other subjects from racial issues}

RESUMO

O artigo pretende analisar, a partir da perspectiva da Sociologia Jurídica, como se dão as relações entre os poderes, o direito e a dominação dos sujeitos dominados pelas classes dominantes. Dessa forma, o artigo, inicialmente, valendo-se da epistemologia crítica do "Norte", faz a análise do processo de dominação, no qual as Ciências Sociais, incluindo o Direito, são elementos essenciais para invisibilizar as lutas sociais. Assim, em seguida, as lutas sociais por novos direitos são analisadas como formas que levam a uma "tomada de consciência" das classes dominadas, levando-as a enveredar pelos caminhos das reivindicações por direitos que the foram e são renegados. Finalizando, o trabalho, a partir de uma epistemologia do "Sul", analisa como têm sido enfrentadas as questões dos novos direitos na América Latina, partindo do pressuposto segundo o qual a questão racial é um dos elementos fundamentais para a compreensão do processo de dominação inaugurado pela Modernidade. A metodologia consistiu na revisão crítica da literatura, incluindo os debates proporcionados pela Sociologia Jurídica, que informa que o direito não é isento de pretensões, mas um instrumento que pode estar a serviço, de forma invisível, das classes dominantes.

Palavas-chave: Poderes. Direito. Dominação. Tomada de consciência. Questão racial. 
The article aims the analysis, from the perspective of Juridical Sociology, how the relations between powers, law, domination and dominated individuals take place. At first, the issue adopts the Northern critical epistemology to analyze the process of domination, in which the Social Sciences, including Law, are essential elements to make invisible social struggles. Thus, the social struggles for new rights are examined as ways to lead dominated classes to awareness, taking them to follow the paths of demanding for their rights, which have been and still are denied. Concluding, by approaching a Southern epistemology, the paper analyses how the issues on new rights in Latin American have been faced, assuming that the racial question is one of the fundamental elements in order to understand the process of domination unveiled by Modernity. The methodology is based on a critical review of literature, including the debates provided by Juridical Sociology, which informs that Law is not exempt from exhortations, being, in fact, an instrument that may be used, invisibly, by dominating classes for dominating others, as a rule.

Keywords: Powers. Law. Domination. Awareness. Racial question.

\section{INTRODUÇÃO}

O artigo pretende analisar, a partir da perspectiva da Sociologia Jurídica, como se dão as relações entre os poderes, o direito e a dominação dos sujeitos dominados pelas classes dominantes, fazendo um recorte a partir das questões raciais presentes na América Latina ${ }^{1}$, em especial a questão negra e indígena no Brasil. Porém, esta última, por razões metodológicas, não terá enfoque específico, o que tornaria a questão bastante abrangente: até mesmo a questão racial dos negros, no Brasil, possui uma abrangência enorme, o que requer recortes espaciais e temporais. Assim, o trabalho, inicialmente, apenas abordará questões gerais em torno da temática.

A metodologia consistiu na revisão crítica da literatura, incluindo os debates proporcionados pela Sociologia Jurídica, que informa que o direito não é isento de pretensões, mas um instrumento que pode estar a serviço, de forma invisível, das classes dominantes.

\footnotetext{
1 Aníbal Quijano (2005) alerta que o processo atual de globalização é, em primeiro lugar, a culminação de um processo que começou com a constituição da América e do capitalismo colonial/moderno e eurocentrado como um novo padrão de poder mundial; um dos eixos fundamentais desse padrão de poder é a classificação social da população mundial de acordo com as ideias de raça, que seria uma construção mental que expressa a experiência básica da dominação colonial e que desde então permeia as dimensões mais importantes do poder mundial, no que se inclui a sua racionalidade específica, o eurocentrismo.
} 


A metodologia
consistiu na
revisão crítica
da literatura,
incluindo
os debates
proporcionados
pela Sociologia
Jurídica, que
informa que
o direito não
é isento de
pretensões, mas
um instrumento
que pode estar
a serviço, de
forma invisível,
das classes
dominantes.

A metodologia revisão crítica da literatura, incluindo os debates proporcionados pela Sociologia Jurídica, que informa que o direito não é isento de pretensões, mas

A forma como se estabelece as relações entre poderes, direito e dominação parece já ter sido abordada por alguns autores, dentre eles o sociólogo francês Pierre Bourdieu (2010), quando tratou do Poder Simbólico. Na obra o pensador demonstra que o direito, antes de mostrar sua força, mostra-se dominar, primeiramente, por sua simbologia, pela sua aparência de imparcialidade e por todo um conjunto de regras que costuma naturalizar os processos de dominação e negação dos direitos das classes dominadas.

Para fazer a correlação entre poderes, direito e dominação, o trabalho é dividido em 03 (três) tópicos. 0 primeiro, a partir de uma epistemologia crítica do "Norte", trata a respeito das contribuições de Pierre Bourdieu para as Ciências Sociais, e em especial para a Sociologia Jurídica. O questionamento que norteia o capítulo é: como é possível que práticas sociais opressoras tenham sido silenciadas no passado e ainda sejam desconsideradas no presente? Um bom caminho para a resposta é analisar o que Pierre Bourdieu denominou de $O$ poder simbólico, um poder quase mágico, em sua expressão.

Evidentemente, a magia desse poder é apenas uma metáfora. Logo, o segundo ponto do trabalho é entender como, historicamente, o processo de dominação se formou em sociedades ditas "subalternas", como a América Latina, em especial no Brasil. A partir desta constatação o artigo começa a tratar da tomada de consciência, inclusive intelectual, que tem permeado os povos que sofreram o processo de colonização inaugurado pela Modernidade. Partindo do conceito de epistemologia do "Sul", procura-se reinterpretar a Modernidade seguindo as lições de Enrique Dussel: os sujeitos renegados podem tomar consciência da dominação e, a partir das lutas sociais, empreender a reescrita do direito.

Como reescrever os direitos e descolonizá-los? Eis a inquietação do terceiro tópico do artigo. Os direitos podem ser descobertos, reinventados ou reescritos, mas é preciso que os saberes e os próprios direitos sejam descolonizados. Tomar consciência das questões raciais que permearam o processo de colonização, e que ainda se fazem presentes, é uma das alternativas, conquanto não seja a única. 


\section{O PODER QUASE MÁGICO E A DOMINAÇÃO SIMBÓLICA: AS CONTRIBUIÇÕES DE PIERRE BOURDIEU PARA A SOCIOLOGIA JURÍDICA}

Ao tratar da relação entre poder e dominação, Anthony Giddens ${ }^{2}$ recorda que o poder, em um sentido bastante generalizado, significa uma capacidade transformadora, uma técnica de intervir em determinado cenário de eventos de forma a alterá-los. Dessa forma, torna-se necessário compreender a conexão lógica entre a ação e o poder, dada a suma importância dessa relação para a teoria social. Nesse sentido, o trabalho procurará fazer essa correlação partindo das contribuições de outro sociólogo: Pierre Bourdieu.

As teorias sociológicas de Pierre Bourdieu podem ser consideradas parte do construtivismo estruturalista, e se baseiam em uma tríade conceitual formada por capitais (cultural, social e simbólico, além do econômico; este último já tratado pela teoria marxista, mas que não será objeto do enfoque principal do teórico) ${ }^{3}$, campo (espaço de conflitos e de concorrência, no qual se luta pelo estabelecimento do monopólio do capital pertinente ao campo) e habitus (conjunto de conhecimentos práticos adquiridos ao longo do tempo que permitem ao sujeito perceber, agir e evoluir com naturalidade em um dado universo social), que constituem o seu referencial de análise da realidade social ${ }^{4}$. A inovação do pensamento do sociólogo francês, no que concerne ao estudo do capital, é a compreensão de que os capitais econômico e cultural são elementos estruturantes de toda a hierarquia social moderna ${ }^{5}$.

O conceito central de "capital", por exemplo, foi desenvolvido por outros autores, como o sociólogo francês Pierre Bourdieu, com um potencial criativo muito mais penetrante, esclarecedor e sofisticado do que seu uso por Marx. Em primeiro lugar, "capital" deixa de ser apenas uma categoria "econômica", e inclui tudo aquilo que passa a ser decisivo

\footnotetext{
2 GIDDENS, 2008, p. 33.

3 "A noção de capitais é herança da teoria marxista, embasada na determinância das estruturas econômicas como forma de estabelecer a conduta individual. Bourdieu, emprestando a ideia de Marx de capital como relação social que dá poder aos possuidores frente aos despossuídos, estende a noção a outras formas de riqueza, criando três outros tipos de capitais: cultural, social e simbólico; sendo que o capital econômico vai continuar fazendo parte de suas análises, mas sem a preponderância dada a ele pela teoria marxista" (MADEIRA, 2007, p. 20).

4 MADEIRA, 2007, p. 20-21.

5 SOUZA, 2015, p. 153.
} 
para assegurar o acesso privilegiado a todos os bens e recursos escassos em disputa na competição social. Ainda que Bourdieu reconheça que o capital econômico é decisivo para assegurar vantagens permanentes nesta disputa, ele não está sozinho.

Para além do capital econômico, uma das maiores descobertas de Bourdieu para a ciência social crítica foi a da importância, tão central como a do capital econômico, do "capital cultural". Capital cultural para Bourdieu é tudo aquilo que logramos "aprender", e não apenas os títulos escolares ${ }^{6}$.

Por diversas razões, a obra do sociólogo francês teve uma forte aceitação no Brasil', sendo bastante traduzida no país e tornando-se um importante referencial para a compreensão de algumas questões essenciais da Sociologia Jurídica, uma vez que o teórico não deixou passar despercebido de suas análises sociológicas o fenômeno jurídico, principalmente na obra O poder simbólico (2010), especialmente no Capítulo VIII, que trata a respeito da força do direito e sobre os elementos para uma sociologia do campo jurídico.

Mas o que seria o poder, em uma concepção sociológica? Seria possível compreender o poder através de sistemas simbólicos? ${ }^{8}$ Há relação entre os sistemas simbólicos e o direito? Como é possível que as classes dominantes subjuguem as classes dominadas e sufoquem as lutas sociais destas? As respostas de Pierre Bourdieu se mostram convincentes e bastante lógicas, sendo uma espécie de óculos capaz de desembaçar a visão míope das estruturas sociais.

Primeiramente, a visão tradicional de poder e dominação parece ser inovada por Pierre Bourdieu, no momento em que o sociólogo passa a compreendê-la não apenas como algo material. O poder simbólico, em sua compreensão, é um poder invisível, o qual só pode ser exercido com a cumplicidade daqueles que não querem saber que lhe

\footnotetext{
6 SOUZA, 2015, p. 225-226.

7 Sobre a aceitação de Pierre Bourdieu no Brasil, cf. BORTOLUCI; JACKSON; PINHEIRO FILHO, 2015, p. 217-218, para quem "um estudo sobre a recepção de sua obra nesse caso deve levar em conta, antes de tudo, que tal processo se dá por meio de relações assimétricas entre um sistema intelectual periférico e um centro produtor da sociologia, e que a tradição francesa desempenhou papel central na constituição das humanidades no Brasil, desde ao menos o século XIX".

8 "Os símbolos são os instrumentos por excelência da 'integração social': enquanto instrumentos de conhecimento e de comunicação (cf. a análise durkheimiana da festa), eles tornam possível o consensus acerca do sentido do mundo social que contribui fundamentalmente para a reprodução da ordem social: a integração 'lógica' é a condição da integração 'moral'” (BOURDIEU, 2010, p. 10).
} 
estão sujeitos ou mesmo que o exercem; o poder simbólico necessita ser descoberto onde ele se deixa ver menos, onde é completamente ignorado e precisa ser reconhecido ${ }^{9}$. Nesse ponto, pode causar certa angústia a leitura das análises do sociólogo quando o mesmo ressalta que a dominação necessita da cumplicidade do dominado.

Evidentemente que, para ser exercido, o poder necessita de sistemas que o estruturem. Nesse sentido, os "sistemas simbólicos", como instrumentos de conhecimento e comunicação, só podem exercer um poder estruturante porque são estruturados; o poder simbólico seria um poder de construção da realidade que tende a estabelecer

$O$ poder simbólico, em sua compreensão, é um poder invisível, o qual só pode ser exercido com a cumplicidade daqueles que não querem saber que lhe estão sujeitos ou mesmo que 0 exercem; o poder simbólico necessita ser descoberto onde ele se deixa ver menos, onde é completamente ignorado e precisa ser reconhecido. uma ordem gnosiológica, isto é, dá um sentido imediato ao mundo, principalmente ao mundo social, o que impede questionamentos pelos sujeitos, supondo aquilo que Durkheim teria chamado de conformismo lógico, ou seja, "uma concepção homogênea do tempo, do espaço, do número, da causa, que torna possível a concordância entre inteligências" ${ }^{10}$.

Nessa perspectiva, os padrões ou sistemas simbólicos atuarão, de forma oculta, como formas de dominação, e darão o conformismo lógico para que as classes dominadas não façam suas reinvindicações, inclusive no campo do direito, bloqueando e desmobilizando, por um lado, as lutas sociais e, por outro lado, naturalizando as desigualdades existentes, uma vez que tuteladas, dentre outras coisas, pela suposta imparcialidade do fenômeno jurídico. E como isso é possível? A maior contribuição do sociólogo, nessa questão, foi a análise das diversas formas de capital, dando enfoque aos capitais simbólicos e culturais. Em síntese, Pierre Bourdieu dirá que,

A cultura dominante contribui para a integração real da classe dominante (assegurando uma comunicação imediata entre todos os seus membros e distinguindo-os das outras classes); para a integração fictícia da sociedade no seu conjunto, portanto, à desmobilização (falsa consciência) das classes dominadas; para a legitimação da ordem estabelecida por meio do estabelecimento das distinções (hierarquias) e para a legitimação dessas distinções. Esse efeito ideológico, produ-lo a cultura dominante dissimulando a função de divisão na função de comunicação: a cultura que une (intermediário de comu-

\footnotetext{
9 BOURDIEU, 2010, p. 8.
}

10 BOURDIEU, 2010, p. 9. 
nicação) é também a cultura que separa (instrumento de distinção) e que legitima as distinções e compelindo todas as culturas (designadas como subculturas) a definirem-se pela sua distância em relação à cultura dominante ${ }^{11}$.

Para que o quadro acima ocorra, os sistemas simbólicos, enquanto instrumentos estruturados e estruturantes de comunicação e de conhecimento, cumprem uma função política de instrumentos de imposição ou de legitimação da dominação. Sua grande contribuição é assegurar a dominação de uma classe sobre outra, através da violência simbólica, dando o esforço de sua própria força às relações de poder que as fundamentam e contribuindo assim, segundo a expressão de Max Weber, para a 'domesticação dos dominados'12. Um exemplo claro disso pode ser representado por meio do fenômeno cultural, como se discutirá adiante, no qual o padrão eurocêntrico branco foi sendo naturalizado como padrão civilizatório de desenvolvimento a ser alcançado pelos povos que sofreram o processo de colonização ${ }^{13}$.

Sobre o processo de dominação, a análise de Pierre Bourdieu procura demonstrar que as diferentes classes e frações de classes estão envolvidas em uma luta propriamente simbólica, na tentativa de imposição de uma definição de mundo social que mais se adeque aos seus interesses, assim como a imposição do campo das tomadas de posições ideológicas reproduzem, em forma transfigurada, o campo das posições sociais ${ }^{14}$. Tais lutas são travadas nos conflitos simbólicos da vida quotidiana, que, de forma delegada, por meio da luta travada pelos especialistas da produção simbólica, tentam impor determinada realidade social. Um exemplo, considerando a problemática que esse artigo levanta, pode ser retratado na forma como as grandes corporações midiáticas geralmente enaltecem os

\footnotetext{
11 BOURDIEU, 2010, p. 11.

12 BOURDIEU, 2010, p. 11.

13 "A expressão mais potente da eficácia do pensamento científico moderno - especialmente em suas expressões tecnocráticas e neoliberais hoje hegemônicas-é o que pode ser literalmente descrito como a naturalização das relações sociais, a noção de acordo com a qual as características da sociedade chamada moderna são a expressão das tendências espontâneas e naturais do desenvolvimento histórico da sociedade. A sociedade liberal constitui-de acordo com esta perspectiva- não apenas a ordem social desejável, mas também a única possível. Essa é a concepção segundo a qual nos encontramos numa linha de chegada, sociedade sem ideologias, modelo civilizatório único, globalizado, universal, que torna desnecessária a política, na medida em que já não há alternativas possíveis a este modo de vida" (LANDER, 2005, p. 21-22).

14 BOURDIEU, 2010, p. 11-12.
} 
padrões de vida e consumo brancos, dando distinção aos seus personagens ou em suas propagandas. Por outro lado, negras, negros e indígenas são inviabilizados ou quase não têm qualquer destaque, sendo apresentados como rudes, primitivos, criminosos, sem perspectivas, dentre tantos outros estereótipos.

Para romper com esse estado de dominação, devem os sujeitos dominados tomar consciência desse processo:

A destruição deste poder de imposição simbólico radicado no desconhecimento supõe a tomada de consciência do arbitrário quer dizer, a revelação da verdade objetiva e o aniquilamento da crença: é na medida em que o discurso heterodoxo destrói as falsas evidências da ortodoxia, restaurando fictícia da doxa, e lhe neutraliza o poder de desmobilização, que ele encerra um poder simbólico de mobilização e de subversão, poder de tornar atual o poder potencial das classes dominadas ${ }^{15}$.

Não se pode deixar de lembrar que, especificamente, em relação às questões raciais no Brasil, Pierre Bourdieu, juntamente com Löic Wacquant (2005), criticaram, na obra Sobre as artimanhas da razão imperialista, a imposição de um modelo binário de relações raciais no Brasil ${ }^{16}$. Tal imposição resultaria da transferência não refletida de categorias sociológicas desenvolvidas para o contexto norte-americano à realidade social do Brasil; desse modo, as relações raciais se conformariam de maneira mais flexível e as classificações seriam mais diversas e contextuais. No entanto, tais análises foram consideradas simplistas e geraram críticas acadêmicas tanto de autores estrangeiros como de brasileiros ${ }^{17}$.

Porém, conquanto se discorde com algum ponto da teoria de Pierre Bourdieu, o importante é reconhecer as suas contribuições a respeito do capital simbólico e dos processos de dominação. As categorias lançadas ou trabalhadas pelo sociólogo, atualmente,

\footnotetext{
15 BOURDIEU, 2010, p. 15.

16 "Realizada por estadunidenses ou latino-americanos formados nos Estados Unidos (ou por programas patrocinados por estadunidenses em seu próprio país), a maior parte da pesquisa recente sobre desigualdade étnico-racial no Brasil tenta provar que, ao contrário da imagem que os brasileiros têm de sua própria nação, o país das três raças tristes (os povos indígenas, os negros descendentes dos escravos e os brancos saídos da colonização ou das ondas subsequentes de imigração europeia) não é menos 'racista' que os outros e que sob esse aspecto os 'brancos' brasileiros nada têm a invejar de seus primos norte-americanos. Pior ainda, o racismo mascarado brasileiro deveria, por definição, ser considerado mais perverso, por ser dissimulado e negado" (BOURDIEU; WACQUANT, 2005, p. 215).

17 BORTOLUCI; JACKSON; PINHEIRO FILHO, 2015, p. 241.
} 
são essenciais em uma perspectiva da Sociologia Jurídica, em que pese o mesmo não ter escrito especificamente sobre esse ramo do conhecimento; com essa perspectiva sociológica, a análise dos processos estruturantes de dominação, o trabalho passa a investigar o processo de dominação que se formou e consolidou com a Modernidade.

\section{A MODERNIDADE REINTERPRETADA POR ENRIQUE DUSSEL}

A Modernidade foi inaugurada segundo uma concepção racionalista, na qual os conhecimentos advindos dos saberes técnicos e formais $^{18}$ foram privilegiados ${ }^{19}$. Nessa perspectiva, a humanidade, em seu núcleo racional, teria alcançado a emancipação do estado de imaturidade cultural e civilizatória; porém, como mito, no horizonte mundial, acabou sacrificando os homens e as mulheres do mundo periférico, colonial. Nesse novo contexto, os ameríndios foram os primeiros a serem explorados, por sua vez a vitimização foi encoberta com o argumento do sacrifício ou custo da modernização ${ }^{20}$. Sobre o tema, Frantz Fanon dizia:

O domínio colonial, porque total e simplificador, logo fez com que se desarticulasse de modo espetacular a existência cultural do povo subjugado. A negação da realidade nacional, as novas relações jurídicas

\footnotetext{
18 Veja-se o exemplo do sistema escolar: "a influência do 'currículo oculto' nos processos de educação formal é aqui provavelmente decisiva. O que é transmitido à criança no ensino da ciência não é apenas o conteúdo das descobertas técnicas mas, mais importante para as atitudes sociais gerais, uma aura de respeito pelo conhecimento técnico de todos os tipos. Na maioria dos sistemas educacionais modernos, o ensino da ciência começa sempre pelos 'princípios primeiros', conhecimento visto como mais ou menos indubitável. Apenas se alguém permanece aprendendo ciência por algum tempo é que poderá ser introduzido a questões contenciosas ou tornar-se plenamente cônscio da falibilidade potencial de todas as reivindicações ao conhecimento em ciência. A ciência tem assim por longo tempo mantido uma imagem de conhecimento fidedigno que se verte numa atitude de respeito para com a maioria das formas de especialidade técnica" (GIDDENS, 1991, p. 92).

19 "As ciências sociais se constituem como tais num contexto espacial e temporal específico: em cinco países liberais industriais (Inglaterra, França, Alemanha, as Itália e os Estados Unidos) na segunda metade do século passado. No corpo disciplinar básico das ciências sociais - no interior das quais continuamos hoje habitando- estabelece-se em primeiro lugar uma separação entre passado e presente: a disciplina história estuda o passado, enquanto se definem outras especialidades que correspondem ao estudo do presente. Para o estudo deste último delimitam-se âmbitos diferenciados correspondentes ao social, ao político e ao econômico, concebidos propriamente como regiões ontológicas da realidade histórico social. A cada um destes âmbitos separados da realidade histórico-social corresponde uma disciplina das ciências sociais, suas tradições intelectuais, seus departamentos universitários: a sociologia, a ciência política e a economia. A antropologia e os estudos clássicos definem-se como o campo para o estudo dos outros" (LANDER, 2005, p. 33).

20 DUSSEL, 1993, p. 152.
} 
introduzidas pela potência ocupante, o lançamento à periferia, pela sociedade colonial, dos indígenas e seus costumes, a usurpação, a escravização sistematizada dos homens e das mulheres tornam possível essa obliteração cultural. [...] Envidam-se todos os esforços para levar o colonizado a confessar a inferioridade de sua cultura transformada em condutas instintivas, a reconhecer a irrealidade de sua nação e, finalmente, o caráter inorganizado e inacabado de sua própria estrutura biológica. Em face dessa situação, a reação do colonizado não é unívoca. Enquanto as massas mantêm intactas as tradições mais heterogêneas para a situação colonial, enquanto o estilo artesanal se solidifica num formalismo cada vez mais estereotipado, o intelectual lança-se freneticamente na aquisição furiosa da cultura do ocupante, tendo o cuidado de caracterizar pejorativamente sua cultura nacional, ou encastela-se na enumeração circunstanciada, metódica, passional e rapidamente estéril dessa cultura ${ }^{21}$.

Como exemplo disso, nada mais contundente do que o caso das sociedades africanas, detentoras de tradições orais milenares, mas desprezadas pelos brancos, que viam essa tradição apenas como sintoma de analfabetismo fundamental ${ }^{22}$, já que a invenção de Johannes Gutenberg ${ }^{23}$ transformou a alfabetização em um importante valor da sociedade ocidental ${ }^{24}$. Dessa forma, apenas determinados modos de conhecimento foram consideradas adequadas para o processo de desenvolvimento, ou seja, o conhecimento dos especialistas, treinados

\footnotetext{
21 FANON, 1968, p. 197-198.

22 "Nas culturas tradicionais, o passado é honrado e os símbolos valorizados porque contêm e perpetuam a experiência de gerações. A tradição é um modo de integrar a monitoração da ação com a organização tempo-espacial da comunidade. Ela é a maneira de lidar com o tempo e o espaço, que insere qualquer atividade ou experiência particular, sendo estes por sua vez estruturados por práticas sociais recorrentes. A tradição não é inteiramente estática, porque ela tem que ser reinventada a cada nova geração conforme assume sua herança cultural dos precedentes. A tradição não só resiste à mudança como pertence a um contexto no qual há, separados, poucos marcadores temporais e espaciais em cujos termos a mudança pode ter alguma forma significativa" (GIDDENS, 1991, p. 44).

23 "Nas culturas orais, a tradição não é conhecida como tal, mesmo sendo estas culturas as mais tradicionais de todas. Para compreender a tradição, como distinta de outros modos de organizar a ação e a experiência, é preciso penetrar no espaço-tempo de maneira que só são possíveis com a intervenção da escrita. A escrita expande o nível do distanciamento tempo-espaço e cria uma perspectiva de passado, presente e futuro onde a apropriação reflexiva do conhecimento pode ser destacada da tradição designada. Nas civilizações prémodernas, contudo, a reflexividade está ainda em grande parte limitada à reinterpretação e esclarecimento da tradição, de modo que nas balanças do tempo o lado do 'passado' está muito mais abaixo, pelo peso, do que o do 'futuro'. Além disso, na medida em que a capacidade de ler e escrever é monopólio de poucos, a rotinização da vida cotidiana permanece presa à tradição no antigo sentido" (GIDDENS, 1991, p. 44-45).

24 JONES,1973, p. 5.
} 
na tradição ocidental; o conhecimento dos "outros", o saber "tradicional" passa a ser considerado não pertinente e como forma de obstáculo à tarefa transformadora do desenvolvimento ${ }^{25}$.

Além disso, não em vão, através do direito e de seu poder simbólico, foram sendo construídas teorias jurídicas para justificar a dominação sobre negros e indígenas ${ }^{26}$, inclusive ao se negar a falta de capacidade intelectual e a ausência de personalidade jurídica aos mesmos.

Ainda no plano cultural, tal registro é importante porque se deve estar consciente de que a cultura se relaciona íntima e inevitável com as outras esferas, entendida como um fenômeno complexo que, na prática, não pode reduzir-se às formas privilegiadas que o colonialismo escolheu para transmitir seus valores e seu conhecimento através do racionalismo. Desde que a Modernidade "sacralizou" a ciência como forma de relacionar-se com o mundo e com os outros, com uma suposta linguagem acreditável e objetiva, as outras formas de transmitir a cultura foram eliminadas ou consideradas secundárias, a exemplo da espiritualidade, do intuitivo e da sensibilidade ${ }^{27}$.

Apesar disso, não se pode esquecer que a Modernidade tem sido objeto de muitos estudos, seja na Sociologia, na Filosofia etc., tratando-se de um fenômeno que não esteve imune às críticas ${ }^{28 .}$ Porém, nesta pesquisa, preferiu-se dialogar com as críticas lançadas por Enrique Dussel, haja vista que se trata de um teórico que empoe sua perspectiva a partir dos sujeitos dominados que não conseguiram usufruir dos frutos das luzes da razão e das promessas não cumpridas da Modernidade (liberté, égualité et fraternité, no célebre lema da Revolução Francesa), perspectiva que acompanha a linha de raciocínio deste trabalho.

\footnotetext{
25 LANDER, 2005, p. 42.

26 Sobre a capacidade intelectual dos povos indígenas, abordando principalmente as posições de Bartolomé de las Casas, cf. os estudos de Lewis Hanke (1958; 1985).

27 ÁVILA SANTAMARÍA, 2011, p. 46.

28 Sem qualquer pretensão exaustiva, cf. alguns trabalhos relevantes sobre a modernidade: GIDDENS, Anthony. As consequências da modernidade (1991); HABERMAS, Jürgen. O discurso filosófico da modernidade: doze lições (2000); GOYARD-FABRE, Simone. Os princípios filosóficos do direto político moderno (2002); MÍLOVIC, Míroslav. Comunidade da diferença: para uma crítica da modernidade; TOURAINE, Alain. Crítica da modernidade (2009); BERTEN, André. Modernidade e desencantamento: Nietzsche, Weber e Foucault (2011); LATOUR, Bruno. Nunca fuimos modernos: ensayos de antropología simétrica (2012).
} 
Enrique Dussel, apesar de considerar a Modernidade como um fato europeu, argumenta que tal fenômeno deve ser visto em relação dialética com o não europeu, ou seja, como conteúdo último de tal fenômeno, podendo dizer-se até que a Europa, em verdade, era até a periferia do mundo muçulmano antes da Modernidade ${ }^{29}$.

Nessa situação, falar de uma Europa como começo, centro e fim da História Mundial - como era a opinião de Hegel - era cair numa miopia eurocêntrica. A Europa Ocidental não era o 'centro', nem sua história nunca fora o centro da história. Será preciso esperar por 1492 para que sua centralidade empírica constitua as outras civilizações como sua 'periferia'. Este fato da 'saída' da Europa Ocidental dos estreitos limites dentro dos quais o mundo muçulmano a prendera constitui, em nossa opinião, o nascimento da Modernidade. 1492 é a data de seu nascimento, da origem da 'experiência' do ego europeu de constituir os Outros sujeitos e povos como objetos, instrumentos, que podem ser usados e controlados para seus próprios fins europeizadores, civilizatórios modernizadores. É essa Europa Ocidental que, pela primeira vez, se lança à conquista do mundo ${ }^{30}$.

Em síntese, não se pode falar em Modernidade sem que se verifique a relação entre a Europa e os outros sujeitos que fizeram parte desse processo. Nesse viés, o ano de $1492^{31}$, segundo a tese central de Enrique Dussel ${ }^{32}$, foi a data de 'nascimento' da Modernidade, não menosprezando o período anterior de gestação. A Modernidade, de tal modo, seria originária das cidades europeias medievais, livres, centros de enorme criatividade; porém, a Modernidade 'nasceu' quando a Europa pôde se confrontar com o seu 'Outro' (América, Ásia, África e Oceania) e controlá-lo, vencê-lo, violentá-lo, enfim, quando pôde se definir como um 'ego' descobridor, conquistador, colonizador da alteridade constitutiva da própria Modernidade, amparada por uma suposta superioridade científica e cultural ${ }^{33}$.

29 DUSSEL, 1993, p. 7.

30 DUSSEL, 1993, p. 113.

31 "De tal maneira que, em primeiro lugar, 1492 é o começo da América Latina. Quer dizer, os indígenas com suas esplêndidas culturas não têm nenhum significado histórico. Em segundo lugar, os latino-americanos são os 'filhos dos imigrantes' - primeiros crioulos, depois mestiços. Em terceiro lugar, são reunidos aos índios emancipados - que pareceria que antes foram dominados e que nada sofreram com a conquista (uma dor necessária da 'modernização') republicanos, participantes então da 'ilustração (Aufklarung)'”' (DUSSEL, 1993, p. 65).

32 DUSSEL, 1993, p. 8.

33 "A cultura nacional é, sob o domínio colonial, uma cultura contestada, cuja destruição 
No campo científico ${ }^{34}$, segundo a versão predominante, o nascimento da Modernidade e a origem de seu "mito" tem como momento de constituição histórica a obra Discurso do método, de René Descartes, ("penso, logo existo": penso, logo conquisto, entenderam os conquistadores), ocasião na qual a Europa se constitui como o "centro" do mundo, em seu sentido planetário, inflando-se o ego europeu de superioridade diante dos demais povos ${ }^{35}$ e dando início a um processo de dominação e colonização sobre aqueles que eram considerados bárbaros ${ }^{36}$, sujeitos ignorantes e desprovidos de racionalidade científica.

A Modernidade não é a mais pura mudança, sucessão de acontecimentos; ela é a difusão dos produtos da atividade racional, científica, tecnológica, administrativa, Por isso, ela implica a crescente diferenciação dos diversos setores da vida social: política, economia, vida familiar, religião, arte em particular, porque a racionalidade instrumental se exerce no interior de um tipo de atividade e exclui qualquer um deles seja organizado do exterior, isto é, em função da sua integração em uma visão geral, da sua contribuição para a realização de um projeto societal, denominado nolista por Louis Dumont. A Modernidade exclui todo o finalismo. A secularização e o desencanto de que nos fala Weber, que definiu a Modernidade pela intelectualização, manifesta a ruptura necessária com o finalismo do espírito religioso que exige sempre um fim da

é empreendida de maneira sistemática. É muito rapidamente uma cultura condenada à clandestinidade. Essa ideia de clandestinidade é imediatamente percebida nas reações dos ocupantes, que interpreta a complacência nas tradições como uma fidelidade ao espírito nacional, como uma recusa à submissão. A persistência nas formas culturais condenadas pela sociedade colonial é já uma manifestação nacional" (FANON, 1968, p. 198-199).

34 "A ideia de Modernidade substitui Deus no centro da sociedade pela ciência, deixando as crenças religiosas para a vida privada. Não basta que estejam presentes as aplicações tecnológicas da ciência para que se fale de sociedade moderna. É preciso, além disso, que a atividade intelectual seja protegida das propagandas políticas ou das crenças religiosas, que a impersonalidade das leis proteja contra o nepotismo, o clientelismo e a corrupção, que as administrações públicas e privadas não sejam instrumentos de um poder pessoal, que a vida púbica e vida privada sejam separadas, assim como devem ser as fortunas privadas do orçamento do Estado ou das empresas. A ideia de Modernidade está, portanto, estreitamente associada à da racionalização. [...] O Ocidente, portanto, viveu e pensou a Modernidade como uma revolução. A razão não reconhece nenhuma aquisição; ao contrário, ela faz tábua rasa das crenças e das formas de organização sociais e políticas que não se baseiem em uma demonstração de tipo científico. [...] A ideologia ocidental da Modernidade, que podemos chamar de modernismo, substitui a ideia de Sujeito e a de Deus à qual ela se prendia, da mesma forma que as meditações sobre a alma foram substituídas pela dissecação dos cadáveres ou o estudo das sinapses do cérebro" (TOURAINE, 2009, p. 18, 19, e 20).

35 DUSSEL, 1993, p. 15.

36 A respeito de como se construiu o discurso de dominação em torno da "barbaridade" dos outros povos, cf. ZEA, Leopoldo. Discurso desde a marginalização e a barbárie (2005). 


\section{[...] a Modernidade se firma a partir da exploração dos "outros" não europeus, que são renegados e ocultados, sendo o processo de colonização essencial para a sua constituição.}

história, realização completa do projeto divino ou desaparecimento de uma humanidade pervertida e infiel à sua missão. A ideia de modernidade não exclui a de fim da história, como testemunham os grandes pensadores do historicismo, Comte, Hegel e Marx, mas o fim da história é mais o de uma pré-história e o início de um desenvolvimento produzido pelo progresso técnico, a liberação das necessidades e o triunfo do Espírito" ${ }^{37}$.

Como se verifica, a Modernidade se firma a partir da exploração dos "outros" não europeus, que são renegados e ocultados, sendo o processo de colonização essencial para a sua constituição. Nesse contexto, não se pode deixar de mencionar alguns conceitos chaves para a compreensão da temática: a colonização designa um processo de aquisição territorial; a colônia é um tipo particular de organização sociopolítica; e, por último, colonialismo é um sistema de dominação. A base dos três conceitos é a noção de expansão de uma sociedade além de seu território (habitat) original ${ }^{38}$.

Portanto, o mito da Modernidade consiste em um processo de racionalização próprio de si mesmo, que elaborou uma alegoria de sua bondade, um "mito civilizador", com o qual se justifica a violência e se declara inocente pelo assassinato dos "Outros". Isso constitui, em verdade, uma gigantesca inversão, na qual a vítima inocente é transformada em culpada, e o opressor culpado é considerado inocente ${ }^{39}$.

Levando adiante o seu mito civilizador, com seu ego inflado, decorrente às novas "conquistas", a Europa avocou para si uma

\footnotetext{
37 TOURAINE, 2009, p. 17.

38 OSTERHAMMEL, Jürgen. Colonialism: a theoretical overview (2005, p. 4-10) apresenta uma visão sucinta e precisa do colonialismo, a partir da epistemologia do Norte. Para ele, os processos de expansão são fenômenos fundamentais da história mundial, tendo ocorrido de seis formas principais: a) migração total de todas as populações e sociedades, sendo que este tipo de expansão geralmente advém de uma conquista militar, subjugação e, frequentemente, suprime as pessoas de regiões alvo de conflito; b) migração individual em massa (emigration), no qual indivíduos, famílias e pequenos grupos deixam seus territórios motivados por fatores econômicos primários, não havendo intenção de retorno; neste caso, os emigrantes não criam colônias, mas costumam se integrar às sociedades multiétnicas, sendo um exemplo disso as Chinatowns estadunidenses; c) colonização de fronteira, em que há uma extensa abertura de terras para uso humano, empurrando uma fronteira para as regiões ainda não exploradas, para fins agrícolas ou para exploração de recursos naturais; d) colônias de povoamento no exterior, sendo exemplo clássico a fase inicial praticada pelos ingleses nos Estados Unidos da América do Norte; e) construção de impérios decorrentes guerras de conquista, sendo que essa forma de expansão possui uma série de variantes; f) construção de redes navais, que é uma forma de expansão marítima que envolve a construção sistemática de fatores tradicionais de proteção militar.

39 DUSSEL, 1993, p. 58-59, 79
} 
centralidade na história universal ${ }^{40}$, menosprezando quaisquer outras narrativas ${ }^{41}$, o que se costumou denominar de eurocentrismo. Por este conceito, em uma visão mais otimista, entende-se que, para aqueles que ainda não atingiram o padrão de modernidade ("os outros"), há necessidade de uma ação civilizatória ou modernizadora por parte dos portadores de uma cultura superior para saírem de seu primitivismo ou atraso, sendo a aniquilação ou civilização imposta os únicos destinos possíveis para os outros ${ }^{42}$.

A América Latina, nesse contexto, ficou fora da história mundial, acontecendo o mesmo com a África. Os países africanos, muito embora haja uma espécie de trindade (Ásia África e Europa, segundo a narrativa de Hegel), ainda assim ficaram igualmente descartados; para além de tudo isso, a "periferia" da Europa serviu de "espaço livre", consagrado pelas teorias jurídicas europeias, para que os pobres de lá, fruto do capitalismo, pudessem se tornar proprietários capitalistas nas colônias ${ }^{43}$.

Sobre a exclusão dos "outros" da Modernidade, Enrique Dussel ${ }^{44}$ critica os pensamentos de Hegel ${ }^{45}$ e Jürgen Habermas (2000); este último ${ }^{46}$, por exemplo, é criticado porque teria ignorado, por

40 Veja-se o argumento de Susan Buck-Morss (2005; 2011), segundo o qual a compreensão do significado da Revolução Haitiana é essencial para se entender a gênese da Modernidade. Sobre os argumentos de Susan Buck-Morss, cf. LIMA (2011).

41 "Da constituição histórica das disciplinas científicas que se produz na academia ocidental interessa destacar dois assuntos fundacionais e essenciais. Em primeiro lugar está a suposição da existência de um metarrelato universal que leva a todas as culturas e a todos os povos do primitivo e tradicional até o moderno. A sociedade industrial liberal é a expressão mais avançada desse processo histórico, e por essa razão define o modelo que define a sociedade moderna. A sociedade liberal, como norma universal, assinala o único futuro possível de todas as outras culturas e povos. Aqueles que não conseguirem incorporar-se a esta marcha inexorável da história estão destinados a desaparecer. Em segundo lugar, e precisamente pelo caráter universal da experiência histórica europeia, as formas do conhecimento desenvolvidas para a compreensão dessa sociedade se converteram nas únicas formas válidas, objetivas e universais de conhecimento" (LANDER, 2005, p. 33-34).

42 LANDER, 2005, p. 34-35.

43 DUSSEL, 1993, p. 19.

44 DUSSEL, 1993, p. 23.

45 Para Edgardo Lander (2005, p. 26-27 e 29), as obras de filósofos como Locke e Hegel tiveram como pressuposto básico o caráter universal da experiência europeia, tendo construído a noção de universalidade a partir da experiência particular da história da Europa, e realizaram a leitura da totalidade do tempo e do espaço da experiência humana sob o ponto de visão dessa particularidade, instituindo uma universalidade radicalmente excludente: "o universalismo da filosofia da história de Hegel reproduz o mesmo processo sistemático de exclusões. A história é universal como realização do espírito universal. Mas desse espírito universal não participam igualmente todos os povos".

46 “Dar uma definição 'europeia' da Modernidade, como faz Habermas, por exemplo - é não entender que a Modernidade da Europa torna todas as outras culturas 'periferia' sua. Trata-se de chegar a uma definição 'mundial' da Modernidade (na qual o Outro da Europa será negado 
completo, o "descobrimento" da América ${ }^{47}$ e o protagonismo da Espanha ${ }^{48}$, que não seriam fatos determinantes constitutivos da Modernidade. Habermas, em sua obra $O$ discurso filosófico da Modernidade, escreveu que "os acontecimentos históricos-chave para a implantação do princípio da subjetividade são a Reforma, a llustração e a Revolução Francesa". Sobre o papel da Espanha, lembra Enrique Dussel:

Essa Espanha, que depois a Europa Ocidental esquecerá e desprezará e que Hegel já não considera Europa - é quem começa a Modernidade. A conquista do México, por sua vez, será a primeira experiência "forte" do ego europeu de controlar outro império, o Outro como servo, como colonizado, como dominado, como explorado e humilhado ${ }^{49}$.

Nesse aspecto, Enrique Dussel (1993) desejou demonstrar o contrário, entendendo que a experiência não só do "descobrimento", mas especialmente da "conquista" foi essencial na constituição do "ego" moderno, não somente como subjetividade "centro" e "fim" da história: na autoconsciência europeia da modernidade, a separação do mundo passa ser entre o ocidental ou europeu, concebido como moderno e avançado, e os "outros", o restante dos povos e culturas do planeta ${ }^{50}$.

Logo, a conquista ibérica do continente americano é o momento inaugural de dois processos que, de forma articulada, conformarão a história posterior: a modernidade e a organização colonial do mundo. Com o início do colonialismo na América, inaugura-se não apenas a organização colonial do mundo, mas a própria constituição colonial dos saberes, das linguagens, da memória e do imaginário; dá-se início, também, ao longo processo que culminará em

e obrigado a seguir um processo de 'modernização' (como 'conceito' e não como 'mito'), desde 1502, aproximadamente)" (DUSSEL, 1993, p. 33)

47 "Habermas, por sua vez, acha que o descobrimento da América Latina não tem nenhuma importância para seu argumento: na realidade ela não entra na história - como para Hegel" (DUSSEL, 1993, p. 35).

48 "Para nós é importante incluir a Espanha no processo originário da Modernidade, já que ao final do século XV era a única potência europeia com capacidade de 'conquista' territorial externa (e tinha provado isso na 'reconquista' de Granada) porque desta maneira a América Latina redescobre também seu 'lugar' na história da Modernidade. Fomos a primeira 'periferia' da Europa moderna; quer dizer, sofremos globalmente desde nossa origem um processo constitutivo de 'modernização' (embora naquele tempo não se usasse essa palavra) que depois se aplicará à África e Ásia" (DUSSEL, 1993, p. 15-16).

49 DUSSEL, 1993, p. 114.

50 LANDER, 2005, p. 26. 
[...] consiste $o$ "mito da Modernidade" em vitimar 0 inocente (o Outro), declarando-o causa culpável de sua própria vitimização e atribuindo-se ao sujeito moderno plena inocência a respeito do ato sacrificial. uma grande narrativa universal, nos séculos XVIII e XIX, e no qual, pela primeira vez, organiza-se a totalidade do espaço e do tempo, com todas as culturas, povos e territórios do planeta, presentes e passados; nessa narrativa, evidentemente, a Europa será o centro geográfico e a culminação do movimento temporal ${ }^{51}$.

Para dominar, precisavam os europeus "tornarem-se" racionalmente superiores, inclusive com um sistema jurídico que pudesse chancelar tal superioridade. Aqui, impossível não recordar da teoria de Pierre Bourdieu, anteriormente mencionada. Assim, não sem apoio das nascentes Ciências Sociais ${ }^{52}$, construiu-se o "mito da Modernidade", auto definindo-se, por um lado, a própria cultura como superior, mais "desenvolvida" e, por outro lado, a outra cultura foi determinada como inferior, rude, bárbara, sempre sujeita de uma "imaturidade" culpável; de maneira que a dominação, por meio da guerra e da violência, foi exercida sobre o Outro, que deveria buscar a emancipação, a civilização, a modernização e a integração ao mundo social e jurídico dos dominantes. Nesse ensejo, portanto, consiste o "mito da Modernidade" em vitimar o inocente (o Outro), declarando-o causa culpável de sua própria vitimização e atribuindo-se ao sujeito moderno plena inocência a respeito do ato sacrificial ${ }^{53}$.

Nesse contexto, para dominar, necessitavam os dominantes construírem formas que pudessem garantir o sucesso desse processo: o racismo foi um elemento essencial para tanto, pois, através de um discurso de distinção, amparado por teorias jurídicas, povos foram submetidos a um processo de dominação que continua a se manifestar, mesmo que de forma bastante dissimulada, nos dias atuais, como se verá adiante.

\footnotetext{
51 LANDER, 2005, p. 26.

52 "Com as ciências sociais dá-se o processo de cientifização da sociedade liberal, sua objetivação e universalização e, portanto, sua naturalização. O acesso à ciência, e a relação entre ciência e verdade em todas as disciplinas, estabelece uma diferença radical entre as sociedades modernas ocidentais e o restante do mundo. Dá-se, como aponta Bruno Latour, uma diferenciação básica entre uma sociedade que possui a verdade - o controle da naturezae outras que não o têm" (LANDER, 2005, p. 35). No mesmo sentido, Anthony Giddens (1991, p. 47) aduz que "as ciências sociais estão na verdade mais profundamente implicadas na Modernidade do que as ciências naturais, na medida em que a revisão crônica das práticas sociais à luz do conhecimento sobre estas práticas é parte do próprio tecido das instituições modernas".

53 DUSSEL, 1993, p. 75-76.
} 


\section{O COLONIALISMO, O RACISMO E A TOMADA DE CONSCIÊNCIA DE SUJEITOS RENEGADOS}

O colonialismo e o racismo podem ser considerados como expressões da estrutura de dominação decorrente da Modernidade, pois havia necessidade de que fossem criadas distinções entre os humanos capazes de sustentar as diferenças econômicas $^{54}$ : a criação de teorias jurídicas para sustentar tal empreitada foi essencial.

Do próprio Norte, surgiram questionamentos a respeito do processo de colonização levado adiante, por séculos, pela Europa. Um exemplo contundente e controverso foi, em França, o desempenhado por Jean-Paul Sartre, para quem o colonialismo rejeitou os direitos humanos para os homens e mulheres que ele submeteu à opressão pela violência, cuja conservação se deu pela força da miséria, da ignorância e de um estado de sub-humanidade. Para que se mantivesse como sistema econômico, era essencial ao colonialismo a prática do racismo, inscrito nos próprios fatos, nas instituições, na natureza das trocas e da produção; os estatutos político e social se reforçavam mutuamente, dando feição sub-humana aos dominados (negros e indígenas), já que as declarações de direitos não lhes diziam respeito. Dessa maneira, de forma inversa, se não tinham direitos, os dominados eram abandonados sem proteção às forças desumanas da natureza, às leis da economia ${ }^{55}$. Esses sujeitos estavam totalmente alheios dos benefícios das revoluções burguesas (liberté, égualité et fraternité seriam direitos que Ihes

\footnotetext{
54 "As categorias, conceitos e perspectivas (economia, Estado, sociedade civil, mercado, classes, etc.) se convertem, assim, não apenas em categorias universais para a análise de qualquer realidade, mas também em proposições normativas que definem o dever ser para todos os povos do planeta. Estes conhecimentos convertem-se, assim, nos padrões a partir dos quais se podem analisar e detectar as carências, os atrasos, os freios e impactos perversos que se dão como produto do primitivo ou o tradicional em todas as outras sociedades. Esta é uma construção eurocêntrica, que pensa e organiza a totalidade do tempo e do espaço para toda a humanidade do ponto de vista de sua própria experiência, colocando sua especificidade histórico-cultural como padrão de referência superior e universal. Mas é ainda mais que isso. Este metarrelato da modernidade é um dispositivo de conhecimento colonial e imperial em que se articula essa totalidade de povos, tempo e espaço como parte da organização colonial/imperial do mundo. Uma forma de organização e de ser da sociedade transforma-se mediante este dispositivo colonizador do conhecimento na forma "normal" do ser humano e da sociedade. As outras formas de ser, as outras formas de organização da sociedade, as outras formas de conhecimento, são transformadas não só em diferentes, mas em carentes, arcaicas, primitivas, tradicionais, pré-modernas" (LANDER, 2005, p. 34).

55 SARTRE, 1968b, p. 43.
} 
seriam constantemente renegados), que estabeleciam uma ordem de direitos universais para todos os seres humanos como forma de negar direitos à maioria deles ${ }^{56}$.

Para Jean-Paul Sartre, foi com a presença efetiva de parte de sua força armada que o colonizador interferiu contraditoriamente seu discurso 'civilizador', instaurando o domínio e a exploração sobre a grande maioria da população, com base no uso da força, na imposição cultural, na inquirição de elementos exóticos e na intimidação pelo fogo lançado dos fuzis, símbolo maior de uma suposta superioridade científica, tecnológica, econômica e cultural. Ele também usou a for-

Ao colonizador devia, com seu ego altruísta, ajudar tais povos a superar 0 estado de atraso e "incivilização", pautandose a ordem constitucional vigente em um modelo liberal de igualdade que ocultava 0 reconhecimento dos sujeitos negros e indígenas. ça como instrumento de superioridade cultural, objetivando mudar padrões ancestrais de uma sociedade tribal por meio da imposição do trabalho forçado: os nativos africanos, diziam os colonizadores evolucionistas, seriam os ditos animais em estado de evolução, os seres que um dia o colonizador teria sido, no passado ${ }^{57}$. Ao colonizador devia, com seu ego altruísta, ajudar tais povos a superar o estado de atraso e "incivilização", pautando-se a ordem constitucional vigente em um modelo liberal de igualdade que ocultava o reconhecimento dos sujeitos negros e indígenas. Portanto, a pergunta que aparece é: tal ordem é capaz de efetivar garantias e direitos fundamentais, considerando-se a dimensão da alteridade e da equidade?

Nesse contexto, o racismo, engendrado pelo aparelho de dominação colonial, foi mantido pelas relações de produção que definiram duas espécies de sujeitos: para uns, privilégios e humanidade, homens livres no exercício de seus direitos; para os demais, "os outros", a ausência de direitos e a sanção pela miséria, a fome crônica, a ignorância e a sub-humanidade ${ }^{58}$.

A visão de Jean-Paul Sartre sobre o racismo imperialista europeu de conquistas, as guerras e dominações coloniais, sobre as práticas de intolerância, exploração e humilhação dos povos subjugados, assim como sua crítica sobre uma forma nacional francesa de tradições racistas, que teria se desdobrado na colonização, era uma tentativa de convencer outros intelectuais franceses de que o neocolonialismo seria uma realidade que não poderia ser tratada com indiferença. Para o

\footnotetext{
56 LANDER, 2005, p. 28.

57 ARANTES, 2011, p. 388.

58 SARTRE, 1968b, p. 43
} 
filósofo, o colonizador que escraviza outro homem como se fosse um pedaço de carvão ${ }^{59}$, facilmente substituível por um sangue novo negro, carregaria em seu ser uma ânsia de exploração e espoliação das riquezas naturais sem limites; para o colonizador, o importante era espoliar as riquezas tropicais das colônias para serem transformadas em manufaturas na metrópole, não importando o homem cultural, dotado de sentimentos, de língua, de religiosidade, mas apenas sua força, sua mão-de-obra a serviço da nação colonizadora ${ }^{60}$.

Para justificar tal sistema econômico, o racismo foi essencial, pois é uma das formas de dominação que pode se disfarçar, podendo ser um elemento chave para se compreender diversas questões de desigualdade presentes nas variadas sociedades. Conquanto seja combatido pela legislação, como no Brasil, atualmente persistem formas ocultas de racismo que acabam sendo acobertadas pelo próprio direito. Isso porque o direito só costuma combater as formas mais explícitas, deixando outras formas sob o manto da normalidade.

Como fenômeno complexo, o racismo pode se dar por variadas formas: individualmente, quando um indivíduo considera que as pessoas negras, como um grupo, são inferiores aos brancos, e isso por causa de traços físicos (genotípicos ou fenotípicos), acreditando que tais traços físicos são determinantes de comportamento social, assim como de qualidades morais ou intelectuais; institucionalmente, o racismo pode ser manifestado ou oculto, quando complexas relações inter-relacionais entre as instituições da sociedade fazem com que os efeitos em longo prazo de uma prática institucional sejam negativos, podendo se manifestar na economia, na educação e nos sistemas burocráticos ou de justiça ${ }^{61}$.

Pode se manifestar, ainda, na forma cultura ${ }^{62}$, definindo-se como expressão individual e institucional da superioridade da herança

\footnotetext{
59 A metáfora, aqui, é provocativa, já que o "carvão", preto como o negro, quando árvore, teve vida; agora, o negro, à semelhança da árvore que vira carvão, após retirada a sua liberdade, transforma-se em simples objeto de um sistema de produção, servindo apenas como combustível (força de trabalho), sendo que seu destino é se transformar em cinzas.

60 ARANTES, 2011, p. 387-388.

61 Sobre racismo institucional, cfr. SANTOS (2013).

62 Um exemplo adequado é dado por Enrique Dussel (1993, p. 52): “'coloniza-se' a sexualidade índia, ofende-se a erótica hispânica, instaura-se a moral dupla do machismo: dominação sexual da índia e respeito puramente aparente pela mulher europeia. Dali nasce o filho bastardo (o 'mestiço', o latino-americano, fruto do conquistador e a índia) e o crioulo (o branco nascido no mundo colonial de Índias)".
} 
cultural de uma raça em relação à outra ${ }^{63}$. Sobre a forma cultural, Frantz Fanon advertia:

Todo povo colonizado - isto é, todo povo no seio do qual nasceu um complexo de inferioridade devido ao sepultamento de sua originalidade cultural - toma posição diante da linguagem da nação civilizadora, isto é, da cultura metropolitana.

Quanto mais assimilar os valores culturais da metrópole, mais o colonizado escapará da sua selva. Quanto mais ele rejeitar sua negridão, seu mato, mais branco será64.

[...] é importante falar do racismo cultural porque ele geralmente é uma forma bem engendrada e oculta de dominação, pois o racismo é adequado na medida em que fatores raciais e culturais estão bem correlacionados e constituem uma base sistemática para o tratamento de inferioridade.
Aqui vale lembrar que Pierre Bourdieu e Löic Wacquant (2005) destacaram que o imperialismo cultural tende a se apoiar no poder de universalizar particularismos ligados a uma tradição histórica singular, fazendo com que a mesma não seja reconhecida como tal.

Nesse contexto, é importante falar do racismo cultural porque ele geralmente é uma forma bem engendrada e oculta de dominação, pois o racismo é adequado na medida em que fatores raciais e culturais estão bem correlacionados e constituem uma base sistemática para o tratamento de inferioridade; por exemplo, quando, inicialmente, os europeus encontraram os africanos, os dois grupos apresentavam diferenças culturais elementares; as religiões africanas eram predominantemente politeístas e, em sua maioria, utilizavam-se da magia e da superstição; as religiões europeias, por outro lado, eram monoteístas e acentuavam o pensamento racional, afirmado pela Modernidade ${ }^{65}$. No ponto acima, um dos elementos de dominação colonial residiu na dominação dos elementos culturais dos povos dominados, principalmente nos campos religiosos e da educação. No campo religioso, tal dominação costumou se dar por meio da supressão dos cultos nativos e pelo estabelecimento do cristianismo como religião oficial, estímulo para que os não cristãos se convertessem, afirmação ou estímulo da ordem existente (caso atípico da colonização onde o islã predominava); já no campo educacional, nas Américas, o Espanhol, o Português, o Inglês e o Francês se tornaram línguas obrigatórias, combatendo-se as línguas indígenas ${ }^{66}$.

\footnotetext{
63 JONES, 1973, p. 5, 105 e 117.

64 FANON, 2008, p. 34

65 JONES, 1973, p. 5.

66 OSTERHAMMEL, 2005, p. 97-104.
} 
Como em qualquer processo de dominação, devem os sujeitos oprimidos tomar consciência do processo de dominação. Sob essa perspectiva Jean-Paul Sartre afirma, ao tratar sobre o racismo, "não resta dúvida de que a classe oprimida deve primeiro tomar consciência de si mesma ${ }^{67}$. Mas esta tomada de consciência é exatamente o contrário de uma reimersão em si: trata-se de reconhecer, na ação e pela ação, a conjuntura objetiva do proletariado que pode definir-se através das circunstâncias de produção ou da repartição de bens". Essa tomada de consciência é essencial porque:

O negro não pode negar que seja negro ou reclamar para si esta abstrata humanidade incolor: ele é preto. Está, pois, encurralado na autenticidade: insultado, avassalado, reergue-se, apanha a palavra 'preto' que lhe atiram qual uma pedra; reivindica-se como negro perante o branco, na altivez. A unidade final, que aproximará a todos os oprimidos no mesmo combate, deve ser precedida nas colônias por isso que eu chamaria momento da separação ou da negatividade: este racismo antirracista é o único caminho capaz de levar à abolição das diferenças de raça ${ }^{68}$.

Para ser reconhecido é preciso ser afirmado e, antes de tudo, auto reconhecer-se. Em 1968, ao questionar o sistema de neocolonial francês, Jean-Paul Sartre já advertia que:

Enfim, o Terceiro Mundo se descobre e se fala por esta voz. Sabe-se que ele não é homogêneo e nele ainda se encontram povos escravizados, outros que adquiriram uma falsa independência, outros que se batem para conquistar a soberania, outros, finalmente, que conseguiram a plena liberdade, mas que vivem sob a ameaça constante de uma agressão imperialista. Essas diferenças nasceram da história colonial, o que quer dizer da opressão. Aqui a Metrópole se contentou em pagar alguns senhores feudais: ali, dividindo para reinar, fabricou com todas as peças uma burguesia de colonizados; mais além realizou um golpe duplo: a colônia é ao mesmo tempo de exploração e de povoamento. Assim, a Europa multiplicou as divisões, a oposições, forjou classes e às vezes racismos, tentou através de todos os expedientes provocar e aumentar a estratificação das sociedades colonizadas ${ }^{69}$.

$\mathrm{Na}$ perspectiva sartriana, os povos negros foram desumanizados, como nativos colonizados ou negros deportados, e o encontro com

\footnotetext{
67 SARTRE, 1968, p. 93.

68 SARTRE, 1968, p. 94.

69 SARTRE, 1968b, p. 140.
} 
sua humanidade perdida só será possível quando a palavra "preto" for recuperada diante do branco, e quando for reconhecido como homem preto que é; portanto, por ser um sujeito oprimido em sua raça, é dela que deve tomar consciência ${ }^{70}$, já que foram excluídos da comunidade de comunicação hegemônica inaugurada pela Modernidade. Em uma perspectiva epistemológica do Sul, Aníbal Quijano enfatiza que:

A América constitui-se como o primeiro espaço/tempo de um padrão de poder de vocação mundial e, desse modo e por isso, como a primeira id-entidade da modernidade. Dois processos históricos convergiram e se associaram na produção do referido espaço/tempo e estabeleceram-se como os dois eixos fundamentais do novo padrão de poder. Por um lado, a codificação das diferenças entre conquistadores e conquistados na ideia de raça, ou seja, uma supostamente distinta estrutura biológica que situava a uns em situação natural de inferioridade em relação a outros. Essa ideia foi assumida pelos conquistadores como o principal elemento constitutivo, fundacional, das relações de dominação que a conquista exigia. Nessas bases, consequentemente, foi classificada a população da América, e mais tarde do mundo, nesse novo padrão de poder. Por outro lado, a articulação de todas as formas históricas de controle do trabalho, de seus recursos e de seus produtos, em torno do capital e do mercado mundial.

A ideia de raça, em seu sentido moderno, não tem história conhecida antes da América. Talvez se tenha originado como referência às diferenças fenotípicas entre conquistadores e conquistados, mas o que importa é que desde muito cedo foi construída como referência a supostas estruturas biológicas diferenciais entre esses grupos.

A formação de relações sociais fundadas nessa ideia produziu na América identidades sociais historicamente novas: índios, negros e mestiços, e redefiniu outras. Assim, termos com espanhol e português, e mais tarde europeu, que até então indicavam apenas procedência geográfica ou país de origem, desde então adquiriram também, em relação às novas identidades, uma conotação racial. E na medida em que as relações sociais que se estavam configurando eram relações de dominação, tais identidades foram associadas às hierarquias, lugares e papéis sociais correspondentes, com constitutivas delas, e, consequentemente, ao padrão de dominação que se impunha. Em

70 ARANTES, 2011, p. 392. 
outras palavras, raça e identidade racial foram estabelecidas como instrumentos de classificação social básica da população.

Com o tempo, os colonizadores codificaram como cor os traços fenotípicos dos colonizados e a assumiram como a característica emblemática da categoria racial. Essa codificação foi inicialmente estabelecida, provavelmente, na área britânico-americana. Os negros eram ali não apenas os explorados mais importantes, já que a parte principal da economia dependia de seu trabalho. Eram, sobretudo, a raça colonizada mais importante, já que os índios não formavam parte dessa sociedade colonial. Em consequência, os dominantes chamaram a si mesmos de brancos.

$\mathrm{Na}$ América, a ideia de raça foi uma maneira de outorgar legitimidade às relações de dominação impostas pela conquista. A posterior constituição da Europa como nova id-entidade depois da América e a expansão do colonialismo europeu ao resto do mundo conduziram à elaboração da perspectiva eurocêntrica do conhecimento e com ela à elaboração teórica da ideia de raça como naturalização dessas relações coloniais de dominação entre europeus e não europeus. Historicamente, isso significou uma nova maneira de legitimar as já antigas ideias e práticas de relações de superioridade/inferioridade entre dominantes e dominados. Desde então demonstrou ser o mais eficaz e durável instrumento de dominação social universal, pois dele passou a depender outro igualmente universal, no entanto mais antigo, o intersexual ou de gênero: os povos conquistados e dominados foram postos numa situação natural de inferioridade, e consequentemente também seus traços fenotípicos, bem como suas descobertas mentais e culturais. Desse modo, raça converteu-se no primeiro critério fundamental para a distribuição da população mundial nos níveis, lugares e papéis na estrutura de poder da nova sociedade. Em outras palavras, no modo básico de classificação social universal da população mundia|71.

Essa invasão e a subsequente colonização acabaram por excluir da comunidade de comunicação hegemônica muitos 'rostos', sujeitos históricos, oprimidos, que constituem a "outra face" da Modernidade. Os outros encobertos pelo descobrimento, os oprimidos das nações periféricas, sofredores de uma dupla dominação, são o que se pode considerar como as vítimas inocentes do sacrifício, formando-se como um 'bloco social', em terminologia de Antônio Gramsci,

71 QUIJANO, 2005, p. 228. 


A atual crise do
Estado de Direito
levou a uma crise
de representação
política em
todos os níveis,
seja em âmbito
local, nacional e
global, no qual
as pessoas não
têm voz em
espaços para
poder manifestar
sua vontade e
nem sequer para
poder denunciar
quando decisões
e ações tomadas
e realizadas em
outras fronteiras
afetam suas
vidas.

A atual crise do Estado de Direito levou a uma crise de representação política em seja em âmbito local, nacional e global, no qual as pessoas não têm voz em espaços para poder manifestar que se constitui como povo, como 'sujeito histórico' em certos momentos. Como, por exemplo, na emancipação nacional no começo do século XIX (quando a classe dos crioulos, dominados nesta época pelos espanhóis, pela burocracia e pelos grupos comerciais e financeiros peninsulares, lideraram os processos das lutas contra Espanha e Portugal. Nessa emancipação todas as classes dominadas, o 'bloco social dos oprimidos', adquiriram fisionomia de sujeito histórico e realizaram uma verdadeira revolução política. Posteriormente, durante o transcurso do século XIX, os crioulos passaram de dominados a dominadores da nova ordem neocolonial, periférica, sendo a classe que mediatizava a dominação externa das metrópoles do capitalismo industrial ${ }^{72}$.

Romper com esse paradigma é possível, devendo-se, para tanto, questionar a própria função do conhecimento proporcionado pelas Ciências Sociais, bem como do Estado de Direito, incapaz de atender aos anseios dos sujeitos que ficaram de fora ou não totalmente abrangidos pelo que se denominou de "comunidade de comunicação".

Todavia, como é possível romper com essa lógica de dominação? Como os saberes proporcionados pelas Ciências Sociais podem alicerçar mudanças baseadas em uma sistemática jurídica de reconhecimento e de empoderamento? No caso da América Latina, muitas das respostas não serão encontradas apenas na mera repetição das ideias vindas do Norte, seja da Europa ou dos Estados Unidos. Conquanto não se deva desconsiderar a produção desse conhecimento, deve-se ter em mente que é possível se construir uma epistemologia que envolva a historicidade e a realidade que impera nesta parte do continente.

\section{SABERES E DIREITOS DESCOLONIZADOS: A REINVENÇÃO DOS DIREITOS A PARTIR DE UMA EPISTEMOLOGIA LATINO-AMERICANA}

A atual crise do Estado de Direito levou a uma crise de representação política em todos os níveis, seja em âmbito local, nacional e global, no qual as pessoas não têm voz em espaços para poder manifestar sua vontade e nem sequer para poder denunciar quando decisões e

72 DUSSEL, 1993, p. 159. 
ações tomadas e realizadas em outras fronteiras afetam suas vidas ${ }^{73}$. Nesse cenário, uma parcela elevada dos habitantes da América Latina é constituída por sujeitos que se constituíram como "os outros" da Modernidade, tais como camponeses, trabalhadores urbanos, indígenas e demais povos tradicionais, dentre tantos outros.

Nesse sentido, o direito e o Estado colonial do século XXI entraram em crise porque não puderam dar respostas às demandas de eliminação das exclusões, marginalizações e discriminações; as instituições ocidentais não somente não puderam dar respostas às novas demandas e àquelas que já estavam reprimidas, mas até fortaleceram um sistema social que costuma promover a assimetria, através de instituições tais como a cidadania, a democracia representativa como única forma de expressão política, os direitos humanos lidos como a chave hegemônica-ocidental, a nação, dentre outras; o custo social e cultural da proposta ocidental é muito alto: a descaracterização, a subordinação e a devastação da natureza ${ }^{74}$.

Para a compreensão desse fenômeno, os estudos sobre decolonialidade ${ }^{75}$ têm avançado, e a partir dos mesmos têm surgido novas formas de se interpretar a história universal e local, levando-se, por exemplo, à compreensão de determinados fenômenos jurídicos e suas implicações nas estruturas sociais dos países em desenvolvimento, como ocorre na América Latina, especialmente no Brasil, foco deste trabalho.

No caso da América Latina, o pensamento social tem produzido uma ampla gama de buscas, de formas alternativas de conhecimento, questionando-se o caráter colonial/eurocêntrico dos saberes sociais sobre o continente, o regime de separações que lhes serviram de fundamento e a ideia de modernidade como modelo civilizatório universal ${ }^{76}$, vindo à tona questões como gênero e raça, bastante ocultadas pelo processo de dominação.

\footnotetext{
73 ÁVILA SANTAMARÍA, 2011, p. 32-33.

74 ÁVILA SANTAMARÍA, 2011, p. 49.

75 Dois exemplos de coletâneas com pluralidade de ideais em torno da temática, cf. MIGNOLO, Walter D. (Editor). Local histories/global designs: coloniality, subaltern knowledges, and border thinking (2000); REVATHI, Krishnaswamy; HAWLEY, John C. (Editors). The postcolonial and the global (2008).

76 LANDER, 2005, p. 38.
} 
Romper com um modelo de colonialidade requer uma consciência do papel da ciência, inclusive das Ciências Sociais ${ }^{77}$. Pierre Bourdieu e Löic Wacquant, por exemplo, recordam que a neutralização do contexto histórico, resultante da circulação internacional de textos e do correspondente esquecimento de suas condições históricas de origem, produz uma aparente universalização ampliada do trabalho de 'teorização'"78.

A compreensão e mudança das relações sociais extremamente desiguais na América Latina requer conhecimento da história colonial e do processo de dominação que se firmou no continente. Dessa forma, a recuperação coletiva da história, surgida na América Latina, nos fins da década de 70 (setenta), e implementada como corrente de pensamento durante os anos 80 (oitenta) do século XX, construiu-se em um dos antecedentes mais claros na configuração dos cenários políticos e epistêmicos críticos no campo da memória coletiva ${ }^{79}$, representando uma tomada de consciência em torno das estruturas institucionais passadas, a realidade presente e as perspectivas de futuro dessas estruturas.

Catherine Walsh (2013, p. 26) lembra que a memória coletiva, neste sentido, é a que articula a continuidade de uma oposta decolonial, a qual pode ser entendida como um viver de luz e liberdade em meio às trevas; assim, não é de surpreender a aflição dos agentes coloniais de apagar a luz e, por conseguinte, as tentativas de imposição de molduras de racionalidade fundadas em binarismos dicotômicos: homem/natureza, mente/corpo, civilizados/bárbaros, dentre outras, bem como nas ideais de raça e de gênero.

Assim, não é possível falar em mudanças sociais sem se pensar em mudanças nas relações jurídicas, forte fator de estruturação

\footnotetext{
77 "Na América Latina, as ciências sociais, na medida em que apelaram a esta objetividade universal, contribuíram para a busca, assumida pelas elites latino-americanas ao longo de toda a história deste continente da 'superação' dos traços tradicionais e pré-modernos que têm servido de obstáculo ao progresso e à transformação destas sociedades à imagem e semelhança das sociedades liberais industriais. Ao naturalizar e universalizar as regiões ontológicas da cosmovisão liberal que servem de base a suas constrições disciplinares, as ciências sociais estão impossibilitadas de abordar processos histórico-culturais diferentes daqueles postulados por essa cosmovisão. Caracterizando as expressões culturais como 'tradicionais' ou 'não modernas', como em processo de transição em direção à modernidade, nega-se-lhes toda possibilidade de lógicas culturais ou cosmovisões próprias. Ao colocá-las como expressão do passado, nega-se sua contemporaneidade" (LANDER, 2005, p. 37).

78 WACQUANT, 2005, p. 210.

79 CUEVAS MARIN, 2013, p. 69.
} 
Com o resgate dessa memória coletiva, ou seja, com essa tomada de consciência histórica, tem sido possível construir alternativas teóricas aos modelos sociais e institucionais que haviam sido naturalizados, inclusive com a retomada de discussões raciais, um forte elemento para a compreensão do processo de desigualdade que se mantém no continente. da engenharia institucional latino-americana. Qualquer projeto de mudança social, seja com o reconhecimento ou a ampliação de direitos aos grupos tradicionalmente excluídos, deve ter em mente que as instituições latino-americanas possuem um arcabouço jurídico de proteção de privilégios que remontam ao período colonial e escravagista, devendo-se rememorar a história coletiva do continente, a fim de se ter essa compreensão ${ }^{80}$.

Pilar Cuevas Marín ${ }^{81}$, nesse sentido, recorda que a recuperação coletiva da história se organizou a partir dos seguintes aspectos: a) primeiro surge na América Latina, nos fins da década de 1970 e durante 1980, em resposta ao protagonismo adquirido por setores populares, urbanos e rurais; $b$ ) segundo, esse cenário se encarregou de visibilizar desde os atores protagonistas das demandas sociais e políticas, trajetórias históricas que até esse momento haviam sido subalternizadas pelas narrativas oficiais da história; c) terceiro, na visibilidade de determinadas trajetórias históricas, definiu-se a contribuição teórica e metodológica de experiências e práticas investigativas provenientes da investigação participativa e da educação popular, por uma parte, e da história popular por outra; essas distintas perspectivas, mas em especial a primeira, possibilitaram a emergência da recuperação coletiva da história, entendida como corrente de pensamento; d) quarto, na corrente de pensamento, a recuperação coletiva da história incorporou, como parte de seus discursos fundacionais, os aportes provenientes da teoria marxista, a filosofia e a teologia da libertação, assim como as investigações participativas e a educação popular.

Com o resgate dessa memória coletiva, ou seja, com essa tomada de consciência histórica, tem sido possível construir alternativas teóricas aos modelos sociais e institucionais que haviam sido naturalizados, inclusive com a retomada de discussões raciais, um forte elemento para a compreensão do processo de desigualdade que se mantém no continente.

\footnotetext{
80 “Poderíamos dizer, então, que o aporte da recuperação coletiva da história ao pensamento crítico latino-americano o encontramos no questionamento que esta corrente estabeleceu com seus discursos, práticas e atores, em relação às ordens políticas e intelectuais hegemônicos da sociedade e a academia, nos fins das décadas de 1970 a 1980. Devemos a esta corrente de pensamento o surgimento de múltiplas narrativas históricas e suas correspondentes memórias, que foram subalternizadas pelos regimes de poder instaurados na América Latina desde o período colonial; assim mesmo, pelo papel que posteriormente cumprem os saberes modernos, em especial a história, neste processo de subalternização dessas 'outras' memórias históricas" (CUEVAS MARín, 2013, p. 94).

${ }^{81}$ MARín, 2013, p. 93.
} 
A dominação dos sujeitos indígenas ${ }^{82}$ e negros, acobertada por teorias jurídicas, não foi um processo sem resistência. Houve contínua resistência e luta, muitas vezes encoberta e negada pela história dominante. No caso dos negros:

A resistência dos escravos foi contínua. Muitos deles alcançaram a liberdade pela luta. Testemunho disso são os "quilombos" no Brasil (territórios libertados, em alguns casos com mulheres de afro-brasileiros que desafiaram durante anos os exércitos coloniais) ou as "costas do Pacífico" na América Central (região do refúgio e liberdade dos escravos britânicos na Jamaíca). A ordem escravista-colonial, porém, respondia brutal e sistematicamente a toda tentativa de fuga ou emancipação. Da cultura francesa emanou Le Code Noir ou Recueil des Règlements rendus jusq'a present, uma das expressões mais irracionais da história da humanidade e que sofreram os afrocaribenhos do Haiti, Guadalupe e Martinica durante decênios. Foi um exemplo prototípico do "direito" opressor do mercantilismo capitalista emanado da revolução burguesa moderna: a liberdade da Modernidade "para dentro" (liberdade essencial da pessoa em Hobbes ou Locke) não era contraditório a com a escravidão "para fora" - dupla face do "mito da Modernidade" até 1992, e que a política do Mercado Comum Europeu, que se fecha sobre si, expressa mais uma vez ${ }^{83}$.

Essa negação da história das lutas dos indígenas e negros serviu para retirar a legitimidade das reinvindicações de tais sujeitos, algo que tem sido bastante questionado nas últimas décadas, principalmente a partir da década de 1980, através dos grupos e movimentos organizados em torno da temática.

Vera Maria Ferrão Candau recorda que, apesar da realidade dos grupos e movimentos negros ser muito heterogênea e diferenciada América Latina, é possível afirmar que estes foram grupos, em geral, reduzidos a uma posição de não cidadania até à metade do século passado, fazendo-se necessário recordar que o regime de escravidão persistiu

\footnotetext{
82 "O índio resistirá durante séculos; sua vida cotidiana certamente será afetada de todas as maneiras pelos invasores - mesmo que não seja mais do que pela introdução dos instrumentos de ferro como o machado, que transformará completamente o trabalho agrícola, doméstico, etc. Brutal e violentamente incorporado primeiro à 'encomenda' exploração gratuita do trabalho indígena - depois aos 'repartimentos', sejam agrícolas ou mineiros (a 'mita' andina), para, finalmente, receber salários de fome nas 'fazendas', o índio deverá recompor totalmente sua existência para sobreviver numa opressão desumana: as primeiras vítimas da modernidade - o primeiro 'holocausto' moderno, como o chama Russel Thornton" (DUSSEL, 1993, p. 160).

83 DUSSEL, 1993, p. 164.
} 


No Brasil, por
exemplo,
o racismo,
antes, com forte
viés individual,
fortalece-se
e esconde-se,
agora, nas formas
institucional e
cultural. Ocorre
que essas duas
últimas formas
são muito mais
difíceis de serem
combatidas, já
que, em regra,
encontram-
se ocultas,
invisibilizadas ou
dissimuladas.

da Inglaterra, interessada em expandir seu mercado consumidor.

As colônias converteram-se num mercado. A população colonial é uma clientela que compra. Por conseguinte, se a guarnição tem de ser eternamente reforçada, se o comércio decai, isto é, se os produtos manufaturados e industrializados não podem mais ser exportados, verifica-se que a solução militar deve ser afastada. Um domínio cego de tipo escravista não é economicamente rentável para a metrópole ${ }^{85}$.

A colonização dos países latinos e o seu braço armado, a escravidão, deixaram marcas que se sentem até hoje nestes países. Sob um discurso jurídico, segundo o qual a abolição tornaria dominantes e dominados iguais em direitos, os sujeitos descendentes daqueles que foram escravizados continuam a experimentar um processo contínuo de negação de seus direitos.

No Brasil, por exemplo, o racismo, antes, com forte viés individual, fortalece-se e esconde-se, agora, nas formas institucional e cultural. Ocorre que essas duas últimas formas são muito mais difíceis de serem combatidas, já que, em regra, encontram-se ocultas, invisibilizadas ou dissimuladas.

O direito, por sua vez, focou os esforços em combater principalmente as práticas racistas individuais ${ }^{86}$, inclusive atribuindo todo o peso dessa prática sobre as condutas dos sujeitos, pouco combatendo

84 CANDAU, 2013, p. 148.

85 FANON, 1968, p. 49-50.

${ }_{86}$ Para combater o racismo individual, a legislação penal apresenta 02 (dois) exemplos de tipificação, o racismo (inscrito na Lei no 7.716/1989, que define os crimes resultantes de raça ou de cor) e a injúria racial (prevista no Código Penal, Decreto-Lei no 2.848/1940, no art. 140, §3ㅇ). 
o racismo institucional e cultural, o que contribuiu para difundir o mito da "democracia racial". Um bom exemplo disso é a questão do crime de racismo, previsto na Constituição Federal, que negligenciou o racismo institucional e cultura ${ }^{87}$ e puniu fortemente as práticas individuais ${ }^{88}$, sem que tenha proposto ações afirmativas, que só foram levadas adiante em virtude de um grande percurso de luta, reconhecimento e inclusão ao longo das décadas de 1990 e $2000^{89}$.

87 A Constituição dá diretrizes gerais para o combate do racismo institucional e cultural, sem que tenha traçado os instrumentos de combate: Art. 3 o Constituem objetivos fundamentais da República Federativa do Brasil: [...] IV- promover o bem de todos, sem preconceitos de origem, raça, sexo, cor, idade e quaisquer outras formas de discriminação. [...] Art. 4ㅇ A República Federativa do Brasil rege-se nas suas relações internacionais pelos seguintes princípios: [...] VIIIrepúdio ao terrorismo e ao racismo;

88 Art. 5 ㅇ Todos são iguais perante a lei, sem distinção de qualquer natureza, garantindo-se aos brasileiros e aos estrangeiros residentes no País a inviolabilidade do direito à vida, à liberdade, à igualdade, à segurança e à propriedade, nos termos seguintes: [...] XLII- a prática do racismo constitui crime inafiançável e imprescritível, sujeito à pena de reclusão, nos termos da lei.

${ }^{89}$ O Estatuto da Igualdade Racial (Lei № 12.288/2010), a lei de cotas nas universidades e demais instituições federais de ensino (Lei no 12.711/2012) e a lei de cotas para negros no serviço público do Executivo da União (Lei no 12.990/2014) são contemporâneas ao julgamento da ADPF 186, que julgou constitucional o sistema de cotas implantado pela Universidade de Brasília - UnB: Ementa: ARGUIÇÃO DE DESCUMPRIMENTO DE PRECEITO FUNDAMENTAL. ATOS QUE INSTITUÍRAM SISTEMA DE RESERVA DE VAGAS COM BASE EM CRITÉRIO ÉTNICO-RACIAL (COTAS) NO PROCESSO DE SELEÇÃO PARA INGRESSO EM INSTITUIÇÃO PÚBLICA DE ENSINO SUPERIOR. ALEGADA OFENSA AOS ARTS. 1ㅇ, CAPUT, III, 3ㅇ, IV, 4ㅇ, VIII, 5ㅇ, I, II XXXIII, XLI, LIV, 37, CAPUT, 205, 206, CAPUT, I, 207, CAPUT, E 208, V, TODOS DA CONSTITUIÇÃO FEDERAL. AÇÃO JULGADA IMPROCEDENTE. I - Não contraria- ao contrário, prestigia - o princípio da igualdade material, previsto no caput do art. 5o da Carta da República, a possibilidade de o Estado lançar mão seja de políticas de cunho universalista, que abrangem um número indeterminados de indivíduos, mediante ações de natureza estrutural, seja de ações afirmativas, que atingem grupos sociais determinados, de maneira pontual, atribuindo a estes certas vantagens, por um tempo limitado, de modo a permitir-lhes a superação de desigualdades decorrentes de situações históricas particulares. II - O modelo constitucional brasileiro incorporou diversos mecanismos institucionais para corrigir as distorções resultantes de uma aplicação puramente formal do princípio da igualdade. III - Esta Corte, em diversos precedentes, assentou a constitucionalidade das políticas de ação afirmativa. IV - Medidas que buscam reverter, no âmbito universitário, o quadro histórico de desigualdade que caracteriza as relações étnico-raciais e sociais em nosso País, não podem ser examinadas apenas sob a ótica de sua compatibilidade com determinados preceitos constitucionais, isoladamente considerados, ou a partir da eventual vantagem de certos critérios sobre outros, devendo, ao revés, ser analisadas à luz do arcabouço principiológico sobre o qual se assenta o próprio Estado brasileiro. V- Metodologia de seleção diferenciada pode perfeitamente levar em consideração critérios étnico-raciais ou socioeconômicos, de modo a assegurar que a comunidade acadêmica e a própria sociedade sejam beneficiadas pelo pluralismo de ideias, de resto, um dos fundamentos do Estado brasileiro, conforme dispõe o art.

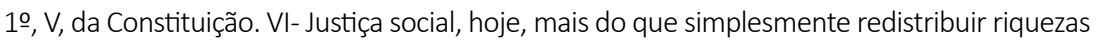
criadas pelo esforço coletivo, significa distinguir, reconhecer e incorporar à sociedade mais ampla valores culturais diversificados, muitas vezes considerados inferiores àqueles reputados dominantes. VII - No entanto, as políticas de ação afirmativa fundadas na discriminação reversa apenas são legítimas se a sua manutenção estiver condicionada à persistência, no tempo, do quadro de exclusão social que lhes deu origem. Caso contrário, tais políticas poderiam converter-se benesses permanentes, instituídas em prol de determinado grupo social, mas em detrimento da coletividade como um todo, situação - é escusado dizer - incompatível com o espírito de qualquer Constituição que se pretenda democrática, devendo, outrossim, respeitar a proporcionalidade entre os meios empregados e os fins perseguidos. VIII - Arguição de descumprimento de preceito fundamental julgada improcedente (ADPF 186, Relator(a): Min. RICARDO LEWANDOWSKI, Tribunal Pleno, julgado em 26/04/2012, ACÓRDÃO ELETRÔNICO DJe205 DIVULG 17-10-2014 PUBLIC 20-10-2014). 
O despertar dos sujeitos renegados, principalmente negros e indígenas, com suas multifacetadas imbricações identitárias, não é um processo simples, pois lidar com as desigualdades de direitos requer mudanças nas estruturas das instituições públicas e privadas, que continuam a manter práticas institucionais que passaram incólumes aos diversos movimentos constitucionais reformistas.

A tomada de consciência dos negros pelo reconhecimento de seus direitos pressupõe a interculturalidade, que deve favorecer a consciência da própria identidade cultural que, em geral, é dinamizada no contraste com o outro, o diferente; trata-se, dessa forma, de processos imbricados e entrecruzados, sendo importante ter em mente que a interculturalidade deve promover o diálogo em bases igualitárias, que não deve dar como pressuposto e ser favorecido pelo mesmo processo intercultural, emponderando-se os grupos que necessitem de uma maior afirmação de sua identidade, para que a igualdade possa ser construída e afirmada na mesma interação intercultura| ${ }^{90}$.

Enrique Dussel deixa claro que a incorporação de "novos" direitos ao "sistema do direito", ou a explosão do "sistema do direito" vigente, que agora se transforma em "antigo", por um novo sistema do direito, é fruto não tanto da explicitação de um direito natural, contudo não descoberto, e sim da institucionalização de um "novo" direito descoberto pelas vítimas "sem-direito", fruto da maturidade histórica própria ao desenvolvimento da realidade humana (e da consciência política), do processo civilizatório da comunidade política particular ou da humanidade em geral ${ }^{91}$.

Esse processo de descoberta, "descobrimento" ou reconhecimento de novos direitos pelos sujeitos renegados não é fruto nem de um estudo teórico nem de um voluntarismo de certos movimentos messiânicos, mas da consciência crítico-política dos grupos que sofrem em sua dor os efeitos negativos do estado-de-não-direito, de uma dimensão humana que a maturidade histórica desenvolveu, mas que o direito não incluiu, contudo, como exigências que requerem institucionalidade pública ${ }^{92}$.

\footnotetext{
90 CANDAU, 2013, p. 156.

91 DUSSEL, 2015, p. 130-131.

92 DUSSEL, 2015, p. 131.
} 
O trabalho, a partir da Sociologia Jurídica, teve como objetivo analisar a relação entre poderes, direito e dominação, relacionando o que se tem denominado de tomada de consciência dos sujeitos sob o enfoque de questões raciais na América Latina, especialmente 0 Brasil.
Portanto, com a tomada de consciência dos sujeitos- negros e indígenas - excluídos do arranjo institucional vigente, é possível a construção ou reconstrução do direito, que não seja mero instrumento de dominação e forma de mascarar os racismos institucional e cultural. Sob essa perspectiva, as questões raciais devem ser discutidas e amplamente debatidas, a fim de que as amarras institucionais do passado venham a lume, única forma de destruí-las e de se construir um Estado de Direito efetivamente igualitário, capaz de proporcionar oportunidades e direitos a todos, e não somente àqueles que se valem das estruturas estruturantes para manter seus privilégios.

\section{CONSIDERAÇÕES FINAIS}

O trabalho, a partir da Sociologia Jurídica, teve como objetivo analisar a relação entre poderes, direito e dominação, relacionando o que se tem denominado de tomada de consciência dos sujeitos sob o enfoque de questões raciais na América Latina, especialmente o Brasil.

Para tanto, com base nas teorias de Pierre Bourdieu, verificou-se que as estruturas estruturantes de dominação se valem do poder quase mágico da dominação simbólica, praticando a violência oculta e dissimulada contra os sujeitos dominados, no que recebem contribuições das Ciências Sociais e do Direito.

O sociólogo Pierre Bourdieu, com enorme aceitação no Brasil, trouxe grande contribuição para as Ciências Sociais, ao perceber que a questão dos capitais não se resume à questão econômica, tratando de outras formas como os capitais econômico e cultural, elementos estruturantes da hierarquia social moderna.

Para Pierre Bourdieu, as diferentes classes e frações de classes estão envolvidas numa luta propriamente simbólica para a imposição de uma definição de mundo social que mais se adeque aos seus interesses, assim como a imposição do campo das tomadas de posições ideológicas reproduzem em forma transfigurada o campo das posições sociais. Tais lutas são travadas nos conflitos simbólicos da vida quotidiana, quer de forma delegada, por meio da luta travada pelos especialistas da produção simbólica, em que se tenta impor determinada realidade social. 
Para romper com esse estado de dominação, devem os sujeitos dominados tomar consciência desse processo e, nesse particular, parece que a lente metodológica que esse artigo oferece permite uma leitura da realidade identificada no desenho institucional vigente, capaz de problematizar os contornos deste espaço.

Conquanto seja natural discordar de algum ponto da teoria de Pierre Bourdieu, o importante é reconhecer as suas contribuições a respeito do capital simbólico e dos processos de dominação; as categorias lançadas ou trabalhadas pelo sociólogo, atualmente, são essenciais em uma perspectiva da Sociologia Jurídica, em que pese o mesmo não ter escrito especificamente sobre esse ramo do conhecimento. com essa perspectiva sociológica, articulada com a análise dos processos estruturantes de dominação, o trabalho passa a analisar o processo de dominação que se formou e consolidou com a Modernidade. Nesse aspecto, a análise deste processo e sua interpretação se dá sobre a abordagem proposta por Enrique Dussel, que aponta a complexidade do tema e destaca como a noção de Modernidade contribuiu para dominação dos sujeitos que ficaram de fora ou não foram abrangidos totalmente pela comunidade da comunicação.

A Modernidade, assim, foi inaugurada segundo uma concepção racionalista, na qual os conhecimentos advindos dos saberes técnicos e formais foram privilegiados, menosprezando as tradições e os conhecimentos dos "outros" que não se adequavam a esse padrão, surgindo daí a colonização e seu elemento essencial: a escravidão e o racismo. Nesse contexto, para dominar, necessitavam os dominantes construir formas que pudessem garantir o sucesso desse processo: o racismo foi um elemento essencial para tanto, pois, através de um discurso de distinção, amparado por teorias jurídicas, povos foram submetidos a um processo de dominação que continua a se manifestar, mesmo que de forma bastante dissimulada, nos dias atuais.

O colonialismo e o racismo, assim, foram expressões dessa estrutura de dominação decorrente da Modernidade, pois havia necessidade de que fossem criadas distinções entre os humanos capazes de sustentar as diferenças econômicas: a criação de teorias jurídicas para sustentar tal empreitada foi essencial.

Do próprio Norte, surgiram questionamentos a respeito do processo de colonização levado adiante, por séculos, pela Europa. Um 
exemplo contundente e controverso foi, em França, o desempenhado por Jean-Paul Sartre, para quem o colonialismo rejeitou os direitos humanos para os homens e mulheres que ele submeteu à opressão pela violência, cuja conservação se deu pela força da miséria, da ignorância e de um estado de sub-humanidade. Para que se mantivesse como sistema econômico, era essencial ao colonialismo a prática do racismo, inscrito nos próprios fatos, nas instituições, na natureza das trocas e da produção; os estatutos político e social se reforçavam mutuamente, dando feição sub-humana aos dominados (negros e indígenas), já que as declarações de direitos

O despertar dos sujeitos renegados, principalmente negros e indígenas, com suas multifacetadas imbricações identitárias, não é um processo simples, pois lidar com as desigualdades de direitos requer mudanças nas estruturas das instituições públicas e privadas [...] não Ihes diziam respeito. Dessa maneira, de forma inversa, se não tinham direitos, os dominados eram abandonados sem proteção às forças desumanas da natureza, às leis da economia.

Romper com o paradigma de dominação e racismo é possível, devendo-se, para tanto, questionar a própria função do conhecimento proporcionado pelas Ciências Sociais, bem como do Estado de Direito, incapaz de atender aos anseios dos sujeitos que ficaram de fora ou não totalmente abrangidos pelo que se denominou de "comunidade de comunicação".

O despertar dos sujeitos renegados, principalmente negros e indígenas, com suas multifacetadas imbricações identitárias, não é um processo simples, pois lidar com as desigualdades de direitos requer mudanças nas estruturas das instituições públicas e privadas, que continuam a manter práticas institucionais que passaram incólumes aos diversos movimentos constitucionais reformistas.

Portanto, com a tomada de consciência dos sujeitos renegados, é possível a construção ou reconstrução do direito, que não seja mero instrumento de dominação e forma de mascarar os racismos institucional e cultural; as questões raciais devem ser discutidas e amplamente debatidas, a fim de que as amarras institucionais do passado venham a lume, única forma de destruí-las e de se construir um Estado de Direito efetivamente igualitário, capaz de proporcionar oportunidades e direitos a todos, e não somente àqueles que se valem das estruturas estruturantes para manter seus privilégios. 


\section{REFERÊNCIAS}

ÁVILA SANTAMARÍA, Ramiro. El neoconstitucionalismo transformador: el Estado y el derecho en la Constitución de 2008. Quito: Abya Yala, 2011.

ARANTES, Marco Antonio. Sartre e o humanismo racista europeu: uma leitura sartriana de Frantz Fanon. In: Sociologias, Porto Alegre, ano 13, no 27, mai./ago. 2011. p. 382-409.

BERTEN, André. Modernidade e desencantamento: Nietzsche, Weber e Foucault. Tradução de Marcio Anatole de Sousa Romeiro. São Paulo: Saraiva, 2011.

BOURDIEU, Pierre. O poder simbólico. Tradução de Fernando Tomaz. 14. ed. Rio de Janeiro: Bertrand Brasil, 2010.

; WACQUANT, Löic. A astúcia da razão imperialista. In: $O$ mistério do ministério: Pierre Bourdieu e a política democrática. Tradução de Paulo Cezar Castanheira. Rio de Janeiro: Editora Revan, 2005, p. 209-230.

BORTOLUCI, José Henrique; JACKSON, Luiz C; PINHEIRO FILHO, Fernando. Contemporâneo clássico: a recepção de Pierre Bourdieu no Brasil. In: Lua Nova, São Paulo, no 94, 2015. p. 217254.

BUCK-MORSS, Susan. Hegel y Haití: la dialética amo-esclavo: uma interpretación revolucionaria. Traducción de Fermín Rodríguez. Buenos Aires: Grupo Editorial Norma, 2005. Hegel e Haiti. In: Novos Estudos - CEBRAP, Tradução de Sebastião Nascimento, São Paulo, no 90, 2011. p. 131-171. CANDAU, Vera Maria Ferrão. Educación intercultural crítica: construyendo caminos. In: WASH, Catherine (org.). Pedagogías decolonialies: práticas insurgentes de resistir, (re)existir y (re)vivir. Quito: Abya Yala, 2013, p. 145-161.

CUEVAS MARÍN, Pilar. Memoria colectiva: hacia un proyecto decolonial. In: WASH, Catherine (org.). Pedagogías decolonialies: práticas insurgentes de resistir, (re)existir y (re)vivir. Quito: Abya Yala, 2013, p. 69-104.

DUSSEL, Enrique. 1492. O encobrimento do outro: a origem do "mito da modernidade". Tradução de Jaime A. Clasen. Petrópolis: Vozes, 1993.

. Direitos humanos e ética da libertação: pretensão política de justiça e a luta pelo reconhecimento dos novos direitos. In: Revista InSURgência, Brasília, ano 01, v. 1, no 01, jan./ jun., 2015. p. 121-135.

FANON, Frantz. Os condenados da terra. Tradução de José Laurênio de Melo. Rio de Janeiro: Civilização Brasileira, 1968. 
. Pele negra, máscaras brancas. Tradução de Renato da Silveira. Salvador: EDUFBA, 2008.

GIDDENS, Antony. As consequências da modernidade. Tradução de Raul Fiker. São Paulo: Editora UNESP, 1991.

. O Estado-Nação e a violência: segundo volume de uma crítica contemporânea ao materialismo histórico. Tradução de Beatriz Guimarães. São Paulo: Editora da Universidade de São Paulo, 2008.

GOYARD-FABRE, Simone. Os princípios filosóficos do direito político moderno. Tradução de Irene A. Paternot. São Paulo: Martins Fontes, 2002.

HABERMAS, Jürgen. $O$ discurso filosófico da modernidade: doze lições. Tradução de Luiz Sérgio Repa e Rodnei Nascimento. São Paulo: Martins Fontes, 2000.

HANKE, Lewis. El prejuicio racial en nuevo mundo: Aristóteles y los indios de hispanoamérica. Traducido por Marina Orellana. Santiago do Chile: Editorial Universitária, 1958.

. La humanidad es una: estudio acerca de la querela que sobre la capacidad intelectual y religiosa de los indígenas americanos sostutivieron en 1550 Bartolomé de las Casas y Juan Ginés. Traducido por Jorge Avendano-Inestrillas y Margarita Sepúlveda de Baranda. 2. ed. Ciudad de México: Fondo de Cultura Econômica, 1985.

JONES, James M. Racismo e preconceito. Tradução de Dante Moreira Leite. São Paulo: Editora Da Universidade de São Paulo, 1973.

LANDER, Edgardo. Ciências Sociais: saberes coloniais e eurocêntricos. In: LANDER, Edgardo (Compilador.). La colonialidad del saber: eurocentrismo y ciências sociales. Perspectivas latinoamericanas. Buenos Aires: CLACSO, 2005, p. 21-53.

LATOUR, Bruno. Nunca fuimos modernos: ensayos de antropología simétrica. Traducción de Víctor Goldstein. Buenos Aires: Siglo Veintiuno Editores, 2012.

LIMA, Enrique Espada. O Haiti e o projeto de uma "História Universal" hoje. In: Afro-Ásia. Salvador, no 44, 2011. p. 287-293.

MADEIRA, Lígia Mori. O direito nas teorias sociológicas de Pierre Bourdieu e Niklas Luhmann. Direito \& Justiça, Porto Alegre, v. 33, n. 1, junho 2007. p. 19-39.

MIGNOLO, Walter D. (Editor). Local histories/global designs: coloniality, subaltern knowledges, and border thinking. Princeton: Princeton University Press, 2000.

MíLOVIC, Míroslav. Filosofia da comunicação: para uma crítica da modernidade. Brasília: Plano Editora, 2002. 
OSTERHAMMEL, Jürgen. Colonialism: a theoretical overview. Translated from German by Shelley L. Frisch. 2. ed. Princeton: Markus Wiener Publishers, 2005.

REVATHI, Krishnaswamy; HAWLEY, John C. (Editors). The postcolonial and the global. Minneapolis: University of Minnessota Press, 2008.SANTOS, Gislene Aparecida dos. Eichmann, o Racismo Institucional e as Políticas Públicas: reflexões sobre o PIMESP e outras políticas. In: Revista Gestão e Políticas Públicas - RGPP, vol. 03, no 01, 2013. p. 113-131.

SARTRE, Jean-Paul. Orfeu negro. In: Reflexões sobre o racismo. Tradução de J. Guinsburg. 5. ed. São Paulo: Difusão Europeia do Livro - DIFEL, 1968, p. 89-125.

. Colonialismo e neocolonialismo. Tradução de Diva Vasconcelos. São Paulo: Tempo Brasileiro, 1968.

SOUZA, Jessé. A tolice da inteligência brasileira: ou como o país se deixa manipular pela elite. São Paulo: Leya, 2015.

QUIJANO, Anibal. Colonialidade do poder, eurocentrismo e América Latina. In: A colonialidade do saber: eurocentrismo e ciências sociais. Perspectivas latino-americanas. Edgardo Lander (org). Buenos Aires: CLACSO, 2005, p. 227-278.

TOURAINE, Alain. Crítica da modernidade. Tradução de Elia Ferreira Edel. 9. ed. Petrópolis: Vozes, 2009.

WALSH, Catherine. Introducción. Lo pedagógico y lo decolonial: entretejiendo caminhos. In: WASH, Catherine (org.). Pedagogías decolonialies: práticas insurgentes de resistir, (re)existir y (re)vivir. Quito: Abya Yala, 2013, p. 24-68.

ZEA, Leopoldo. Discurso desde a marginalização e a barbárie. Tradução de Luís Gonzalo Acosta Espejo e Maurício Delamaro. Rio de Janeiro: Garamond, 2005 . 